\title{
14 Paths of international circulation
}

\author{
How do economists and economic \\ knowledge flow? ${ }^{1}$
}

Elisa Klüger

\section{Introduction}

This chapter draws upon the Brazilian case and weaves a narrative about the patterns and effects of international circulation of economists, economic knowledge and expertise. The text is divided into two sections preceded by methodological considerations. The first section examines how economists and economic ideas flow. It shows how the structure of the Brazilian space of economists was articulated historically and highlights the establishment of connections with foreign experts and institutions. The second section focuses on the patterns of knowledge transposition in order to discuss how dissimilar ideas spread and (re)shape a structured space of economists. The conclusion underlines how internationalization, besides being a source of cosmopolitan capitals for peripheral elites, works as a conduit for ideas and expertise that impact their economies and societies.

Elites $^{2}$ from peripheral countries ${ }^{3}$ have widely relied on internationalization as a strategy to accumulate cosmopolitan assets, which are highly valued in struggles to occupy the dominant positions in local fields of power (Dezalay and Garth, 2002). Cosmopolitan assets are credentials and dispositions resulting from international socialization. To become cosmopolitan, peripheral elites import goods from overseas; mimic manners and fashions; are educated according to foreign standards; and translate and incorporate specialized knowledge, ideas and ideals coming from abroad. Above all, they keep moving around the world. Besides gaining familiarization with foreign landscapes, languages, habits and ideas, international circulation fosters the creation and reinforcement of ties between economic, political and cultural elites from different countries, enlarging the surface of their influence and power (Wagner, 2007).

Contemporaneously, among the most prestigious cosmopolitan qualifications are international academic and professional experiences. The process of modernization of the bureaucracies of peripheral states was accompanied by a strong search for technical credentials, which enhanced the hunt for imported knowledge and expertise. The circulation of knowledge operated both ways: professionals from the center were sent by their governments, universities and philanthropic foundations to peripheral countries while specialists from these 
nations went abroad to receive advanced training. Economics was among the core fields of expertise which benefitted from these circulations, being strategic for those exporting as well as those importing, in a progressively intertwined world economy (Montecinos and Markoff, 2009).

Early in the 20th century, economic experts from the center traveled around, offering formulas aiming at making peripheral economies open and solvent for their creditors. From the 1940s onwards, the United States consolidated its position as the leading source of economic experts and expertise. The dissemination of economic knowledge led by the US operated differently: they provided technical and financial aid as counterparts to political and military alignments, diffusing, withal, their perspectives on the economy and society. From a peripheral perspective, these ties with foreign experts and the experiences abroad were major sources of technical legitimacy and social status (Drake, 1994; Malan et al., 1980).

General statements about the foreign influence over the constitution of the peripheral fields of economics, nonetheless, cannot account for important variations. First, the circulation through different countries fosters diverse perspectives on the economy and streams of economics. Second, each country exporting economic knowledge is permeated by internal struggles, with multiple orientations competing for prestige and international diffusion. Third, political preferences and intellectual configurations in peripheral countries influence how welcomed imported ideas will be. Fourth, the social characteristics of the agents and social networks shape how economic ideas will spread over each space of economists. Focusing on Brazil allows illustrating these variations in a context where international entanglements were decisive since the constitution of its space of economists.

\section{Data and methods}

This chapter is based on a historical reconstruction of the establishment of international bridges through which economists and economic knowledge circulate. These are represented in a network displaying Brazilian economists and liberal professionals who occupied prestigious functions within the public economic administration and in the academic field of economics. It depicts the connections established with foreign agents and institutions, illustrating patterns of internationalization and displaying how these ties are distributed in the Brazilian space ${ }^{4}$ of economists.

The data used to build the network was collected in biographical dictionaries, biographies, CVs, newspapers, pre-existing interviews and interviews conducted by me, between 2012 and 2018, for two different projects: "Meritocracy of Ties: Genesis and Reconfigurations of the Space of Economists in Brazil" and "Theoretical, Political and Social Influences from Exile: The Case of Brazilian Intellectuals in Chile from 1964 to 1973”. These research projects are prosopographic and aim at building a social portrait of several generations of Brazilian economists. The individuals and institutions that integrate 
the network were selected through a "historical" snowball sampling, that is, a qualitative and non-probabilistic technique in which agents and their connections become part of the database when mentioned in interviews, documents and narratives about the Brazilian space of economists.

This network is formed by 440 agents, including individuals, universities, governmental institutions and governments. The ties in the network are bidirectional and non-weighted and indicate connections between agents and institutions or between agents. These are of multiple natures, such as friendship, marriage, professional interactions, political affiliations and association with schools, research centers, governmental bodies or governments. The representation of a wide variety of ties and the simultaneous inclusion of every link that an agent has or had in his or her trajectory derives from the premise that every one of these bonds helps to shape their worldview, practices and position taking and, thus, the institutions they are associated with. Moreover, the number of ties and the social surface reached by an agent are indicators of its volume of social capital, an asset that enhances the ability of an agent to connect agents and groups, currently employed in struggles for influence, power and prestige.

The distances between agents and institutions in the network express the totality of their affiliations, which are the structuring forces of the space and of its polarities. Network analysis is a relational technique that allows representing geometric distances between agents and institutions resulting precisely from the outline of their connections. The network displayed in this chapter was generated using the software Gephi and the distribution of agents and institutions in a bi-dimensional space results from the use of the Force Atlas 2 algorithm. The network is produced by "nodes [that] repulse each other like charged particles, while edges attract their nodes, like springs. These forces create a movement that converges to a balanced state. This final configuration is expected to help the interpretation of the data" (Jacomy et al., 2014, p. 2). This method is relational since the positions of the nodes only acquire meaning in their relation to all others, and its goal is to turn "structural proximities into visual proximities" (idem, p. 2).

Even if space and fields, as conceived by Pierre Bourdieu, and networks are associated with divergent theoretical traditions (Bourdieu, 2000; Becker and Pessin, 2006), current research combines these two frameworks following their common goal of producing spatial representations in which the distances between the unities are relationally defined (Nooy, 2003; Denord, 2003; Serino et al., 2017; Klüger, 2017b). I argue here that the distances in networks - as well as distances in fields - allow representing polarized structures in which the relative position of agents depends on how they are situated vis-à-vis each other in what Bourdieu defines as struggles for determining the dominant principles of domination. Here, however, structural proximity and polarizations are not a direct expression of similarity of habitus and capital composition ${ }^{5}$ of agents that do not necessarily meet - as in a Bourdieusian social space - but are altered repeatedly by their interactions. Therefore, the network has the advantage of displaying concrete ties that can be mobilized at the daily operation of the 
space, "unraveling the processes in which a field is being restructured and symbolic values are (re)produced" (Nooy, 2003, p. 325).

\section{How do economists and economic ideas flow? Learning from the Brazilian case}

The Brazilian space of economists relied on international cooperation since its establishment in the 1940s. The patterns of collaboration with foreign experts and institutions varied according to geopolitical interests and engagement of agents and universities in foreign exchanges. This section illustrates how internationalization influenced the constitution of a Brazilian space of economists and its transformations over time.

\subsection{International cooperation at the genesis of the space of economists - 1940s and 1950s}

The first Brazilians who acquired specialized credentials in economics were, in general, diplomats who studied abroad and public administrators trained in Europe and the United States. By the 1940s, the Brazilian state started to deem economic skills as essential for modernizing and rationalizing economic management. Soon the first departments of economics - which were created by lawyers and engineers - began to recruit foreign professors and establish agreements with universities abroad in order to transfer specialized knowledge on the subject (Loureiro, 1997).

Eugênio Gudin, an engineer with an elite background and vast cosmopolitan capitals, was the main person responsible for the creation, in 1946, of the two major schools of economics in Rio de Janeiro: the National Faculty of Economics (FNCE ${ }^{6}$ later renamed Federal University of Rio de Janeiro, UFRJ $-\mathbf{E 2}^{7}$ ) and the Getúlio Vargas Foundation (FGV - B2). After taking part at the Bretton Woods conference, in 1944, Gudin visited Harvard accompanied by Octavio de Bulhões, a lawyer with a specialization in economics and also a member of the elites. Subsequently, they wrote a report to the Minister of Education stating that the teaching of economics in Brazil should follow Harvard's model - which separated economics from administration and accounting - and recommending hiring North American professors (Gudin, 1979; Silveira 2009).

Gudin managed to recruit some foreign specialists who fled Europe during the World Wars, such as the Czech Alexandre Kafka, the Polish Richard Lewinson and some temporary French, South African, Belgian, Dutch and German professors, causing the FGV to look like a "tower of Babel". Gudin also fostered international connections by inviting foreign professors to give short courses and lectures on contemporary topics and techniques. Among them were the well-known economists Lionel Robbins, from the London School of Economics, Gottfried Haberler, from Harvard, Ragnar Nurkse, from Columbia/Princeton, and Jacob Viner, from Chicago (D’Araújo, 1999). 
Simultaneously, North American specialists were sent to Brazil as part of governmental agreements for economic cooperation. The tonality of the Brazil-US economic diplomacy changed several times during the second half of the 20th century, influencing the rhythm and intensity of the establishment of these connections. Closer interactions and cooperation increased every time that proximity with Latin America became politically strategic, either following the need for supplies and military support during wars or as a strategy for combating the spread of communist ideas within the subcontinent (Malan et al., 1980).

In the 1950s, the outbreak of the Korean War was followed by the promulgation of the Act of International Development, which voiced the intention of making available scientific innovations and technical-industrial progress to the Third World. Based on this act, the Mixed Commission Brazil-US was created (CMBEU - B1). This mission engaged Brazilian and American specialists in preparing projects of infrastructure - mostly energy and transportation - to be financed jointly. The Commission also gave birth to the National Bank of Economic Development (BNDE, later National Bank of Economic and Social Development BNDES - E2), which would be responsible for managing the funding. They recruited qualified personnel and incorporated the knowledge and techniques bequeathed by the CMBEU, becoming the epicenter of development planning in Brazil (Campos, 1994; Sola, 1998).

The CMBEU agreement was terminated in 1953, and a period of diplomatic negligence followed. As the US withdrew from its position of knowledge provider, Brazil went looking for different sources of expertise and sought help from the United Nations' Economic Commission for Latin America (CEPAL - F3). Following up on the great repercussion of Raul Prebisch's manifesto, El desarrollo económico de América Latina y sus principales problemas (1949), CEPAL and its thesis about the necessity of planning and governmental guided industrialization were put on the spot (Garcia, 2005). The BNDE, willing to engage in broader economic planning, convenes with CEPAL to receive a team led by the Sorbonne (F2) trained economist Celso Furtado, the only Brazilian at the Commission. Furtado worked at the BNDE, from 1953 to 1955, to prepare a diagnostic of the productive sector in Brazil for subsidizing an integrated planning of the economy. Furtado's analysis was an important source for Juscelino Kubitschek's Plano de Metas, Brazil's largest experience of state-led economic planning, which focused on the energy, transportation and transformation industry sectors (Furtado, 2014).

This first cooperation led to a follow-up agreement, for the import of CEPAL's "Intensive Training in Problems of Economic Development". The first edition of this course happened in Rio de Janeiro, in 1956, and was inaugurated by President Kubitscheck himself. This course offered a specialization in planning, aiming to prepare bureaucrats and intellectuals for understanding economic activity within a geographical and historical frame and to intervene accordingly to local specificities. The course had 21 editions, in 12 different cities, and lasted until 1967, spreading economic knowledge to regional 
bureaucracies and universities all over the country. In 1960, CEPAL inaugurated an office in Rio de Janeiro, in cooperation with the BNDE, assuming the direction of the courses and centralizing research on Brazil's economy. The CEPAL-BNDE office incorporated young Brazilian economists, notably Maria da Conceição Tavares, Carlos Lessa and Antonio Barros de Castro and influenced a generation of specialists in economics (Klüger et al., 2019, under review).

\subsection{The export of US's economic expertise during the Cold War - 1960s and $1970 \mathrm{~s}$}

While the CEPAL became a leading influence in the formation of public administrators, North American-based mainstream economic knowledge reached the universities. At the beginning of the 1960s, troubled by an increasing antiAmericanism in the region and the proximity between Cubans and Soviets, Kennedy's administration reclaimed a cooperative attitude towards the subcontinent. The rationality subjacent to his "Alliance for Progress" was that the best way to avoid the spread of communism would be to enhance social and economic development, ameliorating well-being. The Alliance promised to foster direct economic investments, transfer modern industrial techniques and agricultural equipment, as well as send experts to areas with a scarcity of qualified professionals to participate in the development of local scientific communities. The United States Agency for International Development, which coordinated these investments, and some non-governmental foundations, such as the Ford Foundation and the Rockefeller Foundation, engaged especially in strengthening scientific fields seen as strategic, including economics (Ribeiro, 2006; Miceli, 1993).

The scientific cooperation comprised investments in university infrastructures, funding of visiting professors and invitations to train local academics, as well as the granting of scholarships to Brazilians who would study economics in the US. These initiatives organized and intensified an international flow of scientists that until this point was unsystematic. Aiming to facilitate these circulations, the Brazilian schools of economics established partnerships and started to prepare the students to apply for positions abroad.

In the 1950s, the School of Administration of the Getúlio Vargas Foundation (EAESP - E5), located in São Paulo, established an exchange program with the Michigan State University (D5) to qualify recently hired professors, like Luiz Carlos Bresser Pereira, who would lead the creation of a school of economics in close connection with studies of public administration (D'Araújo, 1999). In 1960, the FGV-RJ created a Center for Advancement of Economists, which offered supplementary training in mathematics and macro- and microeconomics, as well as three weekly hours of English lessons, preparing their students to pursue graduate courses in the US. They managed to send 16 students overseas until 1964, mostly funded by Rockefeller Foundation scholarships, with their main destinations being Yale (B4), Vanderbilt (B4), and Berkeley (C3) (D’Araújo, 1999; Simonsen, 1966). 
In the mid-1960s, Vanderbilt and Yale established direct agreements with the largest Brazilian schools of economics: FGV and the Faculty of Economics and Administration of the University of São Paulo (FEA-USP - D4). These were intermediated by Alexandre Kafka, who worked at FGV before moving to the International Monetary Fund, and by Werner Baer, a specialist in Latin American Development who had taught at Yale and Vanderbilt and worked as a visiting professor at FGV and USP (Baer, 1998; Kafka, 1998). At that time, Yale's Economic Growth Center master's and Ph.D. programs had a quota for international students. Simultaneously, the USAID financed a cooperation between the FGV and the USP with Vanderbilt's graduate program in economic development, encompassing circulations in both directions. Vanderbilt sent teachers to coach the local professors and offered scholarships for newly graduated Brazilians to pursue their masters and Ph.Ds. in Nashville. Besides, the Ford Foundation provided additional funding for both FGV and USP, fostering a quick professionalization of the graduate training in economics in Brazil (Rocca et al., 1984).

The University of California at Berkeley, in its turn, took part in a different sort of agreement. In 1965, the USAID sent to Rio de Janeiro a technical mission integrated by Berkeley professors and young doctors in economics. Their goal was to help establish the Office for Applied Economic Research (EPEA, later IPEA - C3), a state institution created a year before and directed by João Paulo dos Reis Velloso - who studied at the CAE and was returning from his master's at Yale. Coordinated initially by Howard Ellis and later by Albert Fishlow, the California Mission carried studies of the Brazilian economy and conceived a decennial plan for Brazil's industry, agriculture, infrastructure, as well as education and health. Fishlow simultaneously taught an economic development course at the FGV, sewing ties with the academy. The mission was terminated in 1968 because of political disagreements with the Brazilian government, motivated by the promulgation of the dictatorship's Institutional Act 5 (AI-5), which suspended human rights and deepened censorship and political repression. Fishlow argued that UC Berkeley's progressive political orientation was incompatible with state violence and the suspensions of civil rights, ending the agreement. Nevertheless, the links between Brazil and Berkeley persisted since he took in several Brazilian students, starting with his former assistants at IPEA: Pedro Malan and Regis Bonelli (D’Araújo et al., 2005).

\subsection{The circulations of exiled economic experts - 1960s and 1970s}

The AI-5 also increased the volume of forced international circulation of leftist economists, which were happening since the military takeover of 1964. The exile differed from other circulations of intellectuals given that the accumulation of cosmopolitan dispositions, international credentials and foreign knowledge was an unintended consequence. After the coup, some economists managed to get scholarships in North American universities willing to shelter those facing dangerous situations in Brazil, for instance, Cornell (E5). In 
Europe, the heart of the exile of intellectuals was France, but there were far more social scientists than economists, with very weak links to the Sorbonne (F2) and Nanterre (F3). Some other economists, among which was Celso Furtado, ended up in England, working in Cambridge (F3) and/or Oxford (D3) (Klüger, 2017a).

However, until the mid-1970s, the main destination of the exiled economists was neither Europe nor the US, but Latin America, which led to the establishment of a path for intra-periphery circulations. A large group of intellectuals went to Uruguay right after the military coup, others to Mexico. The epicenter of this reallocation was, nonetheless, Chile. There were political affinities between segments of the exiled community and the Chilean Cristian Democrat administration of Eduardo Frei Montalva and/or the Socialist government of Salvador Allende. These affinities led to the incorporation of Brazilians in both administrations, where they took part in the elaboration of plans for land reform, alphabetization, and economic planning. Finally, Santiago was populated by a dense network of international organizations (including the CEPAL as well as UN's Food and Agriculture Organization and the International Labor Organization) and quartered graduate programs oriented towards the study of Latin American economy and society (Klüger, 2017c).

CEPAL incorporated many of the exiled economists, not only those previously working in its Brazilian office, but also a large share of employees of the Superintendence for the Development of the Northeast (SUDENE - F2), an organization created and coordinated by Celso Furtado, which was under severe surveillance by the military (Furtado, 2014). The graduate programs of the Latin American School of Social Sciences (FLACSO) and of the Latin American School of Economics (ESCOLATINA - G3) received dozens of Brazilian students. ESCOLATINA, during those years, was fairly aligned with CEPAL's economic perspective, as many of the Commission's researchers taught at the school. Both graduate programs were built with North American funds, recruited foreign professors at the beginning and prioritized the building of quantitative analysis skills until the end of the 60s. Following the political radicalization and polarization during Salvador Allende's government, the programs moved towards qualitative frameworks of analysis and became highly politicized. The school of economics advocated for a modern political economy, ${ }^{8}$ with its professors and students engaging in struggles for economic transformations leading to more inclusive and egalitarian societies (Beigel, 2009, Montecinos and Markoff, 2009; Valdés, 1995).

ESCOLATINA, FLACSO and CEPAL were highly affected by the military coup that took place in Chile in 1973. Many among their researchers and professors were dismissed and the critical perspectives that prevailed in the 1960s and early 1970s replaced by highly quantitative models of economics and social sciences that claimed to be universal and politically neutral. The dominant force at the Chilean space of economists were, henceforth, the so-called Chicago Boys, who implemented policies deeply inspired by Milton Friedman's 
neoliberal ideas. In the following years, Chicago's school of economics' (A3) influence spread all over the subcontinent. Even if Brazil had no direct cooperation with Chicago (as was the case for Chile, Argentina and Colombia), professors from Chicago visited Brazil, and students, such as Carlos Geraldo Langoni, were sent to Illinois for their PhDs. They obtained Ford Foundation or USAID scholarships, after attending, at the end of the 1960s, courses offered by IPEA's Center of Training in Economic and Social Development (CENDEC). Headed by an economist with a master's diploma from Chicago, Og Francisco Leme, CEDEC sent students to several universities abroad, notably Chicago, John Hopkins (B3) and Stanford (B5) (Valdés, 1995; Biglaiser, 2002; D’Araújo et al., 2005; Friedman, 2012).

By the end of the 1960s, the exclusive agreements with Vanderbilt, Yale and Berkeley gave place to diversified circulations, with students pursuing their international paths individually. Besides the already mentioned universities of Cornell, Chicago, John Hopkins and Stanford, young Brazilian economists were to be found at the Massachusetts Institute of Technology (C2), Harvard (B2), Princeton (C2) and New York University (D1), among other US universities. The frequency of exchanges with British institutions also rose, including connections with the University of London (C3) and Sussex (G2).

According to Maria Rita Loureiro and Gilberto Tadeu Lima (1994), in 1991, 60\% of the Brazilian professors in economics obtained a $\mathrm{PhD}$ abroad, 46\% in North American universities, 7.5\% in France and 5.5\% in England. The universities with a larger number of graduates were, in order, Vanderbilt, Chicago, Berkeley, Harvard, Michigan and Illinois (Loureiro and Lima, 1994 , p. 38). These numbers are a partial expression of the patterns of international circulation, including only those who stayed at the universities and not those who worked in the government and private sector. Regarding the strong connection with Chile, absent of the data, it should be indicated that those who attended ESCOLATINA obtained only their master's degrees in Chile. Besides, many abandoned the program after the rise of Pinochet's dictatorship. Finally, CEPAL's influence has no expression in $\mathrm{PhD}$ diplomas, with stronger effects on the public administration, given that state bureaucrats were the largest group among those attending the Commission's training program and the exiled working at CEPAL.

\section{How do dissimilar ideas spread and (re)shape a structured space of economists?}

The first step in discussing how international circulation impacted the constitution of the Brazilian space of economists is to map the space and represent the connections between Brazilian and foreign agents and institutions. To do so, I built a synthetic network based on a historical reconstruction of the space of economists in Brazil from the 1940s to the first decade of the 2000s (Klüger, 2017a). The network is inserted into a grid that allows locating and comparing agents' and institutions' positions, and the size of the nodes increases with the number of connections shared by an agent. 


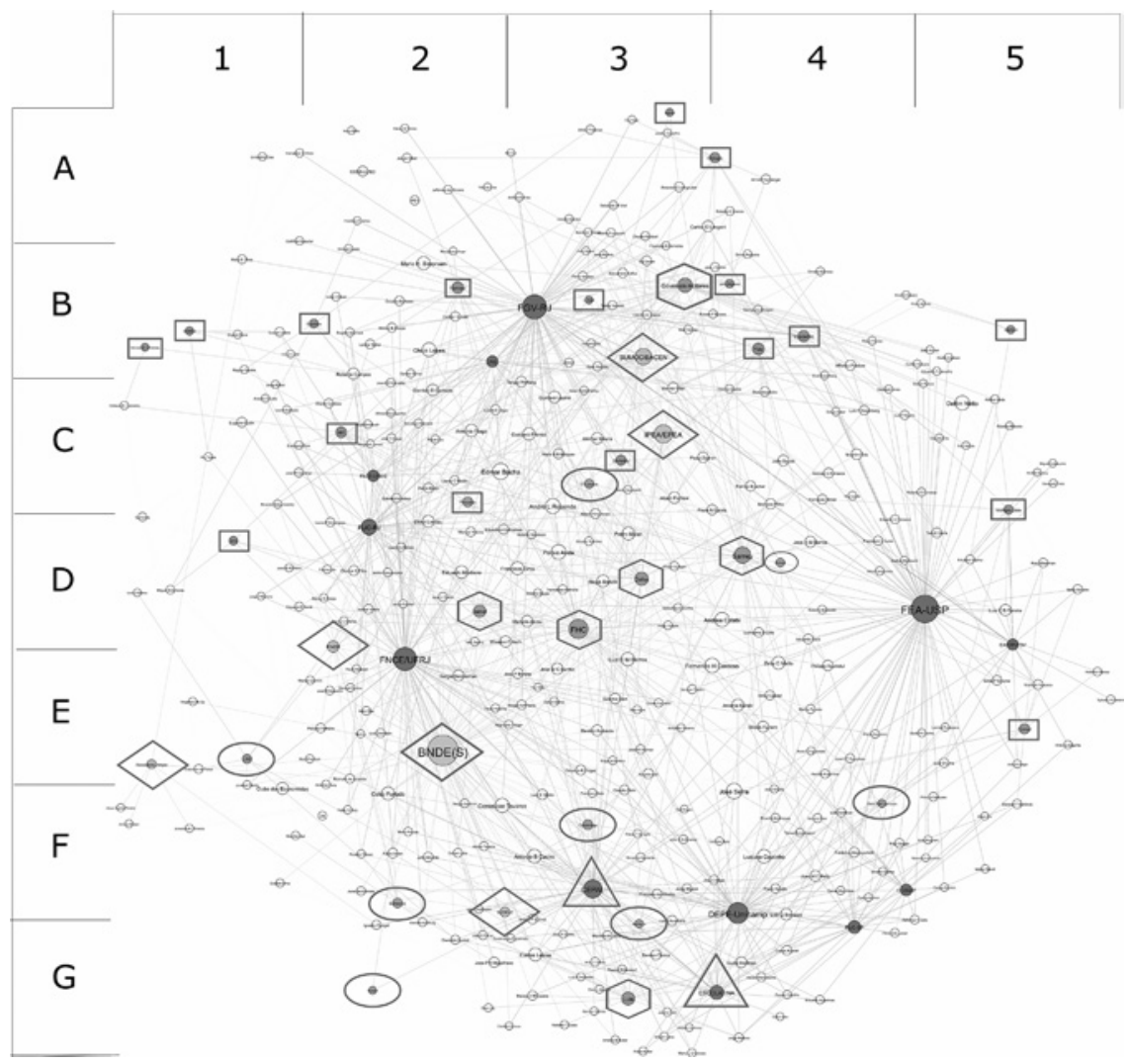

Figure 14.1 The Brazilian space of economists from the 1940s to the 2000s

Triangle: Latin American connections. Circle: European connections. Square: North-American connections. Diamond: governmental economic institutions. Hexagon: presidential administrations from 1964 to 2010. Grey color and no frame: Brazilian schools of economics.

In the network, the horizontal division mirrors regional partitions. Zones $\mathbf{1}$ and $\mathbf{2}$ include mostly economists from Rio de Janeiro and institutions located in Rio, as well as several specialists from the northeast of the country and Minas-Gerais. Zones $\mathbf{4}$ and $\mathbf{5}$ are mainly populated by economists from the state of São Paulo and institutions located in São Paulo, while the central zone 3 has a more balanced regional composition. The distribution also expresses age divisions, with the elderly usually located at the margins of the network, that is zones $\mathbf{1}$ and $\mathbf{5}$, and connected with peers from the same regions.

Along the vertical axis are displayed the patterns of international circulation of economists and economic knowledge. Sectors $\mathbf{A}, \mathbf{B}$ and $\mathbf{C}$ form the zone of North American influence. The European connections spread from $\mathbf{C}$ to $\mathbf{G}$, but are concentrated in area $\mathbf{F}$. Latin American affiliations figure at the sectors 
F and G. The center of the network is mostly restricted to national connections. To understand the impact of different circulations on the configuration of space, it is important to look at the degree of connectivity, represented by the size of the nodes. The average number of connections of a node in the network is 8.26. There are 17 US institutions represented, averaging 8,235 connections (140 total). Among these, Harvard and Yale have almost twice the average of connections. The European institutions are less amalgamated, with eight institutions averaging 5,875 in degree (47 total). Latin America has only two institutions present in the network, but their connectivity is rather strong, averaging 34 in degree (68 total). Even if Latin American links have an average impact of four times the mean weight of US institutions, the sum of the ties with the US is twice the amount of bonds with other Latin American countries. Furthermore, US institutions are more spread over the network, reaching from sectors $\mathbf{A}$ to $\mathbf{E}$, while Latin Americans are limited to sectors $\mathbf{F}$ and $\mathbf{G}$.

The path that goes from $\mathbf{A}$ to $\mathbf{G}$ can be read as a gradient that starts with the most orthodox versions of economics and goes up to the most heterodox ones. Orthodox or monetarist versions of economics can be characterized by their opposition to state interventionism, assuming that the free market would necessarily lead to growth and an optimal distribution of resources. In this view, fiscal austerity, economic stability, openness to foreign trade and no external control were conditions for respecting the market and letting it work at its best (Campos, 1996). This approach usually relies on formalized economic models that taint, with attempts of scientific objectivity and neutrality, the behavioral and ideological fundaments of its analysis (Lebaron, 2000).

Latin American heterodoxy, at the other end of the network $\mathbf{F}$ and $\mathbf{G}$, combines several streams of the modern political economy, including Karl Marx, John M. Keynes, Michal Kalecki, CEPAL's ideas and dependency theory. Against the highly mathematized models of the orthodoxy, they mix economics with historical and sociological analysis, arguing that the historical inequalities that shaped the international division of labor block the economic development of peripheral areas. Therefore, they recommended active economic planning and state-guided industrialization to ensure coordinated efforts of development and reduction of international disparities.

There is a large spectrum of positions between these two extremes. Sectors $\mathbf{B}$ and $\mathbf{C}$ are under the influence of North American mathematized and pro-market economics. The schools represented at these sectors incorporate, nevertheless, critiques of the natural aptitude of the markets, trying to seize its imperfections (as the limited distribution of information, shared externalities, free-riding). Contrary to orthodoxy, they sustain the importance of government intervention to correct some biases, to administrate the offer of public goods and even to invest in strategic sectors that are unattractive to the private market, such as infrastructure and scientific/technologic development. ${ }^{9}$

Sectors $\mathbf{D}$ and $\mathbf{E}$ are predominantly national, and sectors $\mathbf{E}$ and $\mathbf{F}$ are under some European influence, including institutionalist versions of economics, Keynesian economics, studies of industrial organization and of innovation and 
technologic policies. The Brazilian economists studying in Europe between the 1960s and the 1980s were mostly engaged in economic history, history of economic thought or economic and technological development, and many of them were also exiled intellectuals.

Once the gradient of positions is described, the next step is to look at the international connections prevailing in each sector of the Brazilian space of economists.

\subsection{The north of the network - Sectors $A$ and B}

The University of Chicago is represented at the peak of sector A, alongside Virginia and John Hopkins. The Brazilian economists trained in Chicago worked mainly at the FGV and Brazil's Central Bank (SUMOC, later BACEN - B3), both located in $\mathbf{B}$ sector. FGV was slightly pluralist at the beginning, including some professors with nationalist and heterodox perspectives, even though led by liberals like Gudin and Bulhões. After the constitution of its graduate school, the mainstream and mathematized perspectives prevailed and were radicalized when its director, Mario Henrique Simonsen, joined the military administration in the 1970s, being replaced by the Chicago PhD Carlos Langoni. He invited several monetarists, such as Edy Kogut, José Luiz Carvalho, Antonio Lemgruber and José J. Senna, to join him at FGV, and they also attained leadership positions at the Central Bank in the early 1980s (D’Araújo, 1999).

The BACEN is located in the middle of sector $\mathbf{B}$, recruiting directors from all regions of the country. Regarding the Central Banker's highest diploma, only eight of 34 specialists got their diploma in Brazil, three of them at the FGV. Among the others, there are two from British and 24 from North American universities, including four from Harvard, three from MIT, three from Chicago, three from Berkeley, and three from Princeton. The BACEN oscillates, thus, between orthodoxy and some softer versions of mainstream economics.

The National University of Brasília (UNB - B2) is also at sector $\mathbf{B}$, between the FGV and the Faculty of Economic Sciences of the Federal University of Minas Gerais (FACE-UFMG - C2). A recurrent educational trajectory was to be an undergraduate at FACE and a master's student at FGV, and then to pursue a PhD abroad before teaching at the UNB. The UNB recruited most of its economists when they were returning from $\mathrm{PhD}$ programs at Berkeley, Vanderbilt, Yale, MIT and Harvard, universities which are located near the network. Their goal was to establish a mainstream economics department, regarding theory and methods, while being politically critical towards the military and FGVs monetarism (Cunha et al., 2014).

\subsection{The center of the network - Sectors C, D and E}

Sector $\mathbf{C}$ is also under the influence of North American mainstream economics. The IPEA is next to Berkeley, as a result of the circulation promoted by the 
California Mission. The IPEA recruited specialists from diverse backgrounds and different regions of Brazil, spreading its influence widely. Regarding its international connections, the PUC-RJ (D2) is quite similar to the UNB, since many of its professors - Pedro Malan, Chico Lopes, Edmar Bacha previously taught in Brasília. The PUC-RJ hired doctors trained in the US and eventually in Europe. At this school predominated a market-oriented perspective, however critical of the notion of a self-regulating market. For instance, concerning inflation, even if they agreed that fiscal control was important to reach a monetary equilibrium, they perceived behavioral trends that pushed people to inflate prices while assuming that everyone else would do the same. In this case, no monetarist solution could coordinate expectations and settle prices (Bacha, 2012).

The agency for Funding of Studies and Projects (FINEP - D2), located in Rio, designs policies for science/technology and innovation and welcomed several specialists returning from England with expertise on the economic effects of science, technology, and innovation. The University of São Paulo (D4) is situated on the São Paulo side of sector D, at the middle point of the gradient since embracing professors with diversified views of economics. Alongside Delfim Netto and his Delfim Boys, who led the economic administration during the dictatorship, there were younger economists trained in moderate mainstream schools - notably Vanderbilt, Yale and Cornell - and some graduates who identified with Keynesian and/or Marxist ideas.

The EAESP appears close to USP in zone 5, both recruiting most of its professors in the state of São Paulo. As its location on sector $\mathbf{E}$ reveals, EAESP economics differed from that of its Rio alma mater, drawing inspiration from Keynesian and developmentalist ideas. The main international connections of the EAESP are with Michigan and Cornell, located in sector $\mathbf{D}$ and $\mathbf{E}$ respectively. On the Rio de Janeiro side of sector $\mathbf{E}$, there are two large institutions, the FNCE-UFRJ and the BNDES, both inspired by developmentalist perspectives. Many of the Bank cadres and directors have connections with UFRJ, enhancing their proximity in the network. UFRJ has also several ties with institutions located at the south of the network, exchanging several professors with the University of Campinas (UNICAMP).

\subsection{The south of the network - Sectors F and G}

The CEPAL (F3) is a major influence for UFRJ, BNDES and UNICAMP. The BNDE and the CEPAL had a joint office for several years, many of the Banks' bureaucrats attended CEPAL's courses and CEPAL's economists such as Castro, Lessa, and Conceição worked at the Bank. These three senior economists and other experts trained by CEPAL participated in the creation of UNICAMP's economics department, alongside with graduates from the ESCOLATINA who moved to the Campinas after Chile's 1973 military coup (Klüger, 2017c). UNICAMP became the anti-mainstream school of the Brazilian space of economists, combining Marxism, Keynesianism, CEPAL's ideas 
and some conceptions derived from Soviet planning. When UNICAMP's professors pleaded to join the Economics Graduate Association, FGV denied them access, saying that their approach to economics was not "scientific". This battle ended with the FGV leaving the Association, in 1974, because all others backed the UNICAMP's admission (Haddad, 1997).

The UNICAMP was one of the main sources of professors for the Catholic University of São Paulo (PUC-SP - G4) and shared researchers with the Brazilian Center for Analysis and Planning (CEBRAP - G4). The CEBRAP also welcomed researchers returning from exile, some who had worked at the CEPAL or studied at the ESCOLATINA. Professors from Campinas often published in CEBRAP's journal and attended conferences and debates at the Research Center (Belluzzo, 2011). The proximity between CEBRAP, UNICAMP and PUC-SP is based not only on shared personnel but also on compatible ideas. Their economics is open to interdisciplinarity, considering historical, social and geopolitical specificities (Borges et al., 1998).

\subsection{The governments and their economists}

The gradient of positions in the network expresses, thus, the main opposition within the Brazilian space of economists and allows one to observe how diverse sources of foreign economic knowledge spread over the space. Correlations between positions in the space and political position taking, in its turn, can be spotted through the locations of the dots representing the governments from 1964 to 2010. The distances between these reveal how divergent political orientations led to the recruitment of economists with different perspectives.

The military governments appear at the north of the network $(\mathbf{B 3})$, recruiting from the conservative segments of USP, represented by the Delfim Netto and his students, and from FGV, including several of the Chicago-trained economists. All the democratic governments from 1985 until 2002 are located in the center of the network. José Sarney's government (D4) shifted its economic orientation several times. In the beginning, it counted mostly on economists from the FGV, but unsatisfied with their results, recruited an economic team encompassing economists from UNICAMP, USP and PUC-RJ. Fernando Collor de Mello's administration (D3) relied mostly on economists from USP, combined with some professionals from the PUC-RJ, PUC-SP and UFRJ. If Sarney's and Collor's administrations leaned towards São Paulo, their successor, Itamar Franco, was slightly closer to Rio de Janeiro and Minas Gerais (D2). Fernando Henrique Cardoso was Itamar's Minister of Finance, and the antiinflationary plan he launched was key for his victory at the following presidential elections. Once elected (D3), Cardoso kept most of his former economic team, integrated by economists from the PUC-RJ and the USP. Finally, Lula's administration (G3) opposed the military governments diametrically, having assembled heterodox economists from UNICAMP and neighboring schools with strong Latin American connections. 


\section{Elisa Klüger}

\section{Conclusion}

This chapter focused on the Brazilian case in order to analyze the international flow of economists and economic ideas, and how they (re)shape a structured space of economists. The historical reconstruction of its international connections cast light on strategies of technical legitimation of local elites and the effects of their international engagements over the national struggles for prestige and political/administrative power. From the discussion, it is possible to say that there are correspondences between the structure of polarities observed at the national and international levels. As Dezalay and Garth (2002) indicate, these affinities result from a double movement: on the one side, the local elite looks abroad for legitimated sources of knowledge, cosmopolitan capitals and strategic connections; on the other side, internationally dominant forces reinforce their positions geopolitically when sending their experts abroad, exporting ideas and setting a favorable economic agenda worldwide.

The structure of the space expresses an opposition between dominant North American schools of economics and a strong Latin American influence at a scattered heterodox position. The degrees of connections indicate that even if the US has the most extensive influence over the Brazilian space of economists, the connections with CEPAL and ESCOLATINA are the single largest sources of economic knowledge. Between these extremities, there is a myriad of intermediate positions in which mainstream ideas and oppositions to it coexist and recombine. Most of the governments also appear in the center of the network, mixing expertise from several schools.

Further investigation could address the spillover effect of the internationalization of Brazilian economists on the regions where they circulate, inquiring if the ideas emanating from peripheral areas also impact the center. Supplementary research should be conducted to evaluate if those who circulate between the center and the periphery; those who circulate between peripheries and those who do not circulate have different social profiles and compositions of economic, cultural and cosmopolitan capitals. Thus, it will become possible to observe if international circulation led to changes in the social profiles of the elites or if it reinforces inequalities, offering additional cultural, social and symbolic resources to those already affluent.

\section{Notes}

1 This chapter combines results from two research projects: a Ph.D. thesis, funded by CNPQ and CAPES-PSDE grants, conducted at the Department of Sociology of the University of São Paulo, and as visiting researcher at the Université de Picardie Jules Verne and University of California - Berkeley and a postdoc at the Brazilian Center for Analysis and Planning and Princeton University, supported by São Paulo Research Foundation (FAPESP) grants: 2017/13937-1 e 2018/09487-7. I wish to thank the editors for all the helpful remarks and Johanna Gautier, Pierre Benz and Thierry Rossier for their detailed comments and recommendations.

2 Economists were able to make of their expertise a source of prestige that surpassed the academic field, becoming a key to access positions of decision and influence at the state and private sector. 
3 In this chapter, the division between center and periphery is not restricted to the economic aspects that distinguish industrialized countries and those relying on the export of primary goods (Prebisch, 1949). Economic domination is frequently combined with broader cultural dependency, including reliance on foreign technology, knowledge and expertise. Therefore, in this chapter the term periphery indicates dependency on both material and immaterial resources.

4 The use of Bourdieu's amplified notion of space, instead of his concept of field, allows comprising not only the relatively autonomous field of economics but also the governmental institutions responsible for the economic administration and agents that circulate between the academic, public and private sectors.

5 Even though Bourdieu didn't operationalize the links between social affinity and social connections, he and Monique Saint-Martin make clear that the orchestration of habitus and similarity of lifestyles are at the base of the establishment of all kinds of ties, and all achievements in a field that depend on the existence of personal relations (1978, p. 37). Thus, it can be inferred that according to this logic the ties at a network express social similarities/differences.

6 For all institutions, the name has been translated but the acronym will be kept in Portuguese.

7 When a new institution is mentioned, a code indicating its position at the network is added.

8 Modern political economy can be differentiated from mainstream economics based on its interdisciplinary attitude; its critics "against the extensive use of methodological individualism, of equilibrium and harmony concepts, of marginalism, against the exogenous and static character of psychological and sociological assumptions, and against the neglect of historical and dynamic factors"; and its focus on the historical and geographically specific aspects of the economies. It considers that economic outcomes vary accordingly to different cultures and political priorities, which requires studies to be localized and empirical, instead of general models based on predetermined assumptions about the human behavior (Rotschield, 1989, p. 4).

9 David Colander and Arjo Klamer conducted a survey at the graduate schools in economics at the beginning of the 1980s, which helps to differentiate the schools located at points $\mathbf{A}$ and $\mathbf{B}$. The results show that MIT and Harvard students are usually in strict opposition to Chicago. Yale appears in the middle, usually closer to MIT/Harvard. For instance, $70 \%$ of Chicago graduates believed that minimum wage increased unemployment of young and unqualified workers, while only $24 \%$ of the MIT students and 15\% of Harvard graduates agreed. No one from Chicago disagreed with the idea that inflation was purely a monetary phenomenon, $84 \%$ of them agreeing strongly. On the other hand, only $7 \%$ of MIT students and $15 \%$ of Harvard's agreed strongly with that. Finally, only $6 \%$ of Chicago's graduates agreed strongly that "The distribution of income in developed nations should be more equal", against more than 50\% of MIT, Harvard and Yale students (Colander and Klamer, 1987, pp. 103-104).

\section{References}

Bacha, E. (2012). Belíndia 2.0: fábulas e ensaios sobre o país dos contrastes. Rio de Janeiro: Editora Civilização Brasileira.

Baer, W. (1998). Explorando o mundo real. Economia Aplicada, 2(4), 767-770.

Becker, H., \& Pessin, A. (2006). A Dialogue on the Ideas of 'World' and 'Field'. Sociological Forum, 21(2), 275-86.

Beigel, F. (2009). La FLACSO chilena y la regionalización de las ciencias sociales en América Latina (1957-1973). Revista Mexicana de Sociología, 71(2), 319-349.

Belluzzo, L. G. (2011). Luiz Gonzaga Belluzzo por Ricardo Ismael, Rosa Freire D’Aguiar, Alexandre de Freitas Barbosa e Bernardo Ricupero. Cadernos do Desenvolvimento, 6(9), 420-441. 


\section{Elisa Klüger}

Biglaiser, G. (2002). The Internationalization of Chicago's Economics in Latin America. Economic Development and Cultural Change, 50(2), 269-286.

Borges, M. A., Mello, C. H. P., Galvani, C., \& Gomes, W. P. (1998). Memória do Departamento de Economia: a fala de alguns de seus chefes. São Paulo: EDUC.

Bourdieu, P. (2000). Les Structures Sociales de l'économie. Paris: Éditions du Seuil.

Bourdieu, P., \& Saint-Martin, M. (1978). Le patronat. Actes de la Recherche en Sciences Sociales, 20-21, 3-82.

Campos, R. O. (1994). A Lanterna na Popa. Rio de Janeiro: Topbooks.

Campos, R. O. (1996). Entrevista com Roberto Oliveira Campos. In C. Biderman, L. F. Cozac, \& J. M. Rego (Eds.). Conversas com Economistas Brasileiros. São Paulo: Editora 34.

Colander, D., \& Klamer, A. (1987). The Making of an Economist. Journal of Economic Perspectives, 1(2), 95-111.

Cunha, L. R., Leopoldi, M. A., \& Raposo, E. (2014). Dionísio Dias Carneiro, um humanista cético: uma história da formação de jovens economistas. Rio de Janeiro: Editora PUC-Rio/LTC.

D’Araújo, M. C. (1999). Fundação Getúlio Vargas: concretização de um ideal. Rio de Janeiro: Editora FGV.

D'Araújo, M. C., Farias, I. C., \& Hippolito, L. (2005). IPEA 40 anos apontando caminhos: depoimentos ao CPDOC. Brasília: IPEA.

Denord, F. (2003). Genèse et institutionnalisation du néo-libéralisme en France (années 1930 - années 1950) Ph.D. diss. Paris: EHESS.

Dezalay, Y., \& Garth, B. (2002). La Mondialisation des Guerres de Palais: la restructuration du pouvoir d'État en Amérique Latine, entre notables du droit et "Chicago boys". Paris: Éditions du Seuil.

Drake, P. W. (1994). Money Doctors, Foreign Debts, and Economic Reforms in Latin America from the 1890s to the present. Wilmington: Jaguar Books on Latin America.

Friedman, M. (2012). Bases para un desarrollo económico, conferencia en el Edificio Diego Portales de Santiago, el 26 de marzo de 1975. In A. Soto. (Ed.). Un Legado de Libertad: Milton Friedman en Chile [Kindle]. Instituto Democracia y Mercado/Atlas Economic Research Foundation/Fundación para el Progresso.

Furtado, C. (2014). Obra autobiográfica: A Fantasia Organizada, A Fantasia Desfeita, Os Ares do Mundo. São Paulo: Companhia das Letras.

Garcia, A. (2005). Circulation internationale et formation d'une "école de pensée" latinoamericaine (1945-2000). Information sur les sciences sociales, 44 (2/3), 521-555.

Gudin, E. (1979). Carta ao Ministro Gustavo Capanema, 21 de agosto de 1944. In P. E. B. Carneiro (Ed.). Eugênio Gudin visto por seus contemporâneos. Rio de Janeiro: Editora da Fundação Getúlio Vargas.

Haddad, P. R. (1997). Itaipava 30 anos depois: Seminário da USP - Cinquenta Anos de Ciência Econômica no Brasil. FEA-USP, agosto de 1996. In M. R. Loureiro (Ed.). 50 Anos de Ciência Econômica no Brasil: pensamento, instituições e depoimentos. Petrópolis: Editora Vozes.

Jacomy, M., Venturini, T., Heymann, S., \& Bastian, M. (2014). ForceAtlas2, a Continuous Graph Layout Algorithm for Handy Network Visualization Designed for the Gephi Software. PLOS ONE, 9(6).

Kafka, A. (1998). Depoimento Alexandre Kafka. Brasília: Secretaria de Relações Institucionais do Banco Central do Brasil.

Klüger, E. (2017a) Meritocracia de laços: gênese e reconfigurações do espaço dos economistas no Brasil. Ph.D. diss. São Paulo: Universidade de São Paulo.

Klüger, E. (2017b). Espaço social e redes: contribuições metodológicas à sociologia das elites. Tempo social - Revista de sociologia da USP, 29(3), 83-110. 
Klüger, E. (2017c). Circulations périphériques: les effets sur l'espace politique brésilien de l'exil des intellectuels de gauche au Chili entre 1964 et 1973. Revue internationale des études du développement, 230(2), 29-56.

Klüger, E., Wanderley, S., \& Barbosa, A. F. (2019). The CEPAL-BNDE Center and the Building of a Generation of Intellectuals Engaged in Planning the Brazilian Development. Under review.

Lebaron, F. (2000). La Croyance Économique: les économistes entre science et politique. Paris: Éditions du Seuil.

Loureiro, M. R. (1997). Os Economistas no Governo: gestão econômica e democracia. Rio de Janeiro: Editora Fundação Getúlio Vargas.

Loureiro, M. R., \& Lima, G. T. (1994). A internacionalização da ciência econômica no Brasil. Revista de economia política, 14(3), 31-51.

Malan, P., Abreu, M., Bonelli, R., \& Pereira, J. E. C. (1980). Política econômica externa e industrialização no Brasil 1939/1952. Rio de Janeiro: IPEA/INPES.

Miceli, S. (1993). A Fundação Ford no Brasil. São Paulo: Editora Sumaré.

Montecinos, V., \& Markoff, J. (2009). Economists in the Americas. Cheltenham, MA: Edward Elgar.

Nooy, W. (2003). Fields and Networks: Correspondence Analysis and Social Network Analysis in the Framework of Field Theory. Poetics, 31, 305-327.

Prebisch, R. (1949). O desenvolvimento econômico da América Latina e alguns de seus problemas principais. Revista Brasileira de Economia, 3(3), 47-11.

Ribeiro, R. A. (2006). A Aliança para o Progresso e as relações Brasil-EUA. Ph.D. diss. Campinas: UNICAMP.

Rocca, C. A., Ceotto, E., \& Rizzieri, J. A. B. (1984). O Instituto de Pesquisas Econômicas e a Fundação Instituto de Pesquisas Econômicas. In A. P. Canabrava (Ed.). História da Faculdade de Economia e Administração da Universidade de São Paulo (1946-1981). São Paulo: FEA-USP.

Rotschield, K. W. (1989). Political Economy or Economics? European Journal of Political Economy, 5, 1-12.

Serino, M., D’Ambrosio, D., \& Ragozini, G. (2017). Bridging Social Network Analysis and Field Theory through Multidimensional Data Analysis: The Case of the Theatrical Field. Poetics, 62, 66-80.

Silveira, P. B. A. (2009). O estado da ciência e a ciência do Estado: a Fundação Getúlio Vargas e a configuração do campo das ciências econômicas no Brasil. Master thesis. Rio de Janeiro: UFRJ.

Simonsen, M. H. (1966). O Ensino de Economia em nível de Pós-Graduação no Brasil. Revista Brasileira de Economia, 20(4), 19-30.

Sola, L. (1998). Ideias econômicas, decisões políticas: desenvolvimento, estabilidade e populismo. São Paulo: Editora da Universidade de São Paulo/Fapesp.

Valdés, J. G. (1995). Pinochet's Economists: The Chicago School in Chile. Cambridge: Cambridge University Press.

Wagner, A. (2007). Les classes sociales dans la mondialisation. Paris: Éditions la découverte. 